\title{
Language Typology and Tonogenesis in Two Atlantic Creoles
}

\author{
YOLANDA RIVERA-CASTILLO \\ University of Puerto Rico-Rio Piedras
}

\section{Introduction}

Languages belong to three basic types when analyzed according to the assignment of tonal features within phonological units (Hyman 1978, and 1992): intonational (phonological phrases), pitch-accent (fixed position in phonological words), and tonal languages (feet and syllables). Regarding the lexically distinctive nature of tone in languages, Hyman (1992:166) states that

\section{[..] a tone language is a language in which both pitch phonemes and segmental phonemes enter into the composition of at least some morphemes. Tone assignment happens at the lexical or postlexical levels. This distinguishes tonal languages from pitch-accent languages and intonational languages.}

Intonational languages have no lexical tone assignment. Tones in pitch-accent languages are introduced post-lexically since they are not necessarily associated with particular morphemes (Pulleyblank 1986:20). ${ }^{1}$

Papiamentu and Saramaccan, two Atlantic Creoles, have tonal systems. Both have a bitonal system with the mora as the tone bearing unit (TBU), and tonal patterns that distinguish lexical categories. These exhibit downstepping and downdrift; features that are shared with West African languages and are absent, for example, in East Asian tonal languages (Yip 1995). Papiamentu and Saramaccan have partially restricted tonal systems, such as those of some Bantu languages (Voorhoeve 1968).

This paper provides evidence of strong typological similarities between the tonal systems of Papiamentu and Saramaccan with the systems of West African languages. These typological similarities constitute the basis for a proposal that there is a genetic affiliation between Papiamentu and Saramaccan with the Kwa and Bantu language families; an affiliation that reaches beyond the accidental

\footnotetext{
${ }^{1}$ In fact, the distinction between tone languages and pitch-accent languages has been interpreted in many studies as a difference between a restricted and an unrestricted distribution of tone (Hyman 1978, 1992; McCawley, 1978). However, tone languages have different degrees of restrictions regarding tone distribution.
} 
lexical borrowing. Since Saramaccan has been classified as an English-based Creole, and Papiamentu as a Romance-based Creole, their similarities indicate that their substrata have a greater significance in Creole genesis than previously recognized.

Given that there is a strong correlation between typological and genetic relations (Greenberg 1974), Indo-European languages had no influence in Atlantic Creole tonogenesis. Changes in suprasegmental systems typically involve changes from tone --> pitch-accent --> stress-accent (Salmons 1992:272). There are shifts from tonal to stress systems, but no shift from stress to tonal systems (Salmons 1992). Therefore, both Saramaccan and Papiamentu's systems could not have emerged from the systems of their non-tonal lexifiers.

Papiamentu and Saramaccan's tonal systems emerged from their substrata: West African languages at a particular stage of development during the slave trade. Tonal features cannot be borrowed but integrated into the complex, coherent, and self-contained systems of these Creoles. Therefore, this paper explores only general typological features. Similarities regarding specifics of tonal behavior require further study; one that considers the effect of language change in the tonal systems of these Creoles. Also, I assume that tonal features which distinguish West African languages from other language families constitute reliable evidence of genetic affiliation vis a vis features identified as language universals that these Creoles could share with any tonal language.

In the following section (1), this paper presents evidence of similarities between Papiamentu, Saramaccan and West African languages. The parameters discussed include tone levels, tone bearing units, tone patterns associated with grammatical categories, tone spreading, and downstepping. It discusses phenomena that specifically distinguish restricted from non-restricted tone languages such as the type of tone bearing units (syllable or word/foot); fixed tonal patterns versus free tone assignment to grammatical categories; and tone spreading versus tone polarization or anticipation. Finally, Section 2 discusses the similarities and differences between these Creoles.Voorhoeve (1959 and 1961), Rountree (1972), Byrne (1987), and Ham (1999) provided some of our examples and descriptions of Saramaccan. Most of the Papiamentu examples were originally provided by Raúl Römer (1983 and 1991), Harris (1951), Bendix (1983), Rivera (1998), and Pickering and Rivera (2001). Other observations are based on data provided by these authors and on independent research.

\section{Typological Features of Papiamentu and Saramaccan's Tone Systems}

Papiamentu has lexically predetermined tones but also postlexical tone assignment. As a mixed system - -a tone + stress language-Papiamentu combines features of tonal languages with those of stress languages (Rivera 1998). At the lexical level, it constitutes a bitonal system like that of many West African languages. Asian languages usually have a greater number of tones (up to five in some languages).

The Tone Bearing Unit (TBU) is the mora. Tonal systems of West African languages require that every unit carry a tone. For example, Papiamentu has 
contour tones only in long bimoraic stressed syllables (' - High tone; ' - Stress; and Low tone unmarked) (Birmingham 1971:5):

(1) 'dúùna 'to give'

In Asian languages, contour tones can attach to syllables regardless of the number of morae. Contour tones are more numerous in Asian languages and level tones have a more important role in lexical distinctions for African languages (Chen 1992:61). For all practical purposes, morpheme and syllable are co-extensive in Asian languages (Chen 1992:60); and contour tones constitute an inseparable unit linked to a syllable.

On the other hand, Papiamentu has lexically predetermined tone patterns that respond to categorial distinctions (Kouwenberg and Murray 1994). For example, verbs carry tone patterns that distinguish these from nouns:

(2) 'biáhạ 'trip' versus $\quad \begin{aligned} & \text { 'biaháa 'to travel' } \\ & \mathrm{H}-\mathrm{L}-\mathrm{H}\end{aligned}$

Tone in African languages plays an important role in distinguishing grammatical categories (Schuh 1978:251-254). Kwa languages such as Yoruba make extensive use of tone for lexical distinctions (Pulleyblank 1992:263). In Common Bantu there was mostly free tone assignment (Phillipson 1998:316). However, modern Bantu languages like Kimatuumbi and Kikuria exhibit different tonal patterns in the verb stem that respond to differences in tense-mood, and aspect in the verb (Odden 1989 and 1995:449). Although similar patterns are part of the tonal systems of some Asian languages, such as Tokyo Japanese (McCawley 1978:528), most do not rely on these for lexical distinctions, and have lexical free tone assignment.

Postlexically, Papiamentu assigns tonal alternations (polarization) to syllabic sequences within phrasal domains. Alternations result from the application of the Obligatory Contour Principle (OCP) in this tone-to-stress language. Salmons (1992:274) suggests that the application of the OCP operates differently in stress and in tonal languages. In tonal languages, it requires spreading while in stress languages it requires destressing or the creation of non-identical adjacent levels of stress. Indeed, alternating HLHL sequences are characteristic of tone-to stress languages, tonal languages shifting to a stress system. Some African languages, such as Ganda and Hausa, have systems similar to Papiamentu's (Hyman and Katamba 1993, Newman 1995). Nevertheless, tonal alternations are not the only tone shifting mechanism operating in Papiamentu, spreading is also a significant component in its system:

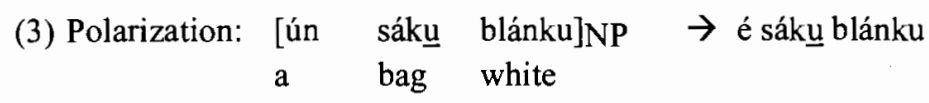

(4) Spreading: é sákụ [á skér]VP $\rightarrow$ é sákú á skér 
Spreading applies only before phrase edges (4); and polarization applies freely in all other contexts.

Chen (1992:54) identifies three parameters that distinguish African from Asian tone languages: tone spreading or movement, metathesis or the melodic inversion of contour tones, and downstep and downdrift. Bao (1992:3) indicates that contour (Asian) as well as level tone (African) languages have tone spreading; however, spreading applies in a restricted fashion in Asian languages since, with few exceptions, every morpheme carries a lexically prespecified tone (Chen 1992:60). Spreading is not restricted in African languages and these even have long distance spreading (Cassimjee and Kisseberth 1992:26). As indicated, there are other postlexical phenomena in Saramaccan and Papiamentu such as downstepping and downdrift, which are characteristic of African languages but are practically absent from Asian languages.

Downstepping and downdrift constitute a gradual lowering of tones adjacent to a L tone. Pickering and Rivera (2001) have found evidence of downdrift in Papiamentu:

$\begin{array}{lllll} & & 225 \mathrm{hz} & 193.42 & 200.45 \\ \text { (5) mi tá } & \text { du'ná- bó } & \text { a- } & \text { r!óz } \\ \text { I PRES give you } & \text { rice } & \end{array}$

In (5), the pitch readings indicate the effect of a $\mathrm{L}$ tone in the following $\mathrm{H}$ tone (! - lowering). Harris (1951), Römer (1991), and Bendix (1983) have also described downdrift effects in Papiamentu. These features show a clear typological connection between Papiamentu and Kwa and Bantu languages.

Saramaccan shares many of these features with Papiamentu. Saramaccan has a bitonal system and its TBU is the mora. Rountree (1972) indicates the presence of mid tones in this language (a tritonal system), but it is unclear at this point whether these are lexically distinctive. However, Ewe, the most likely substratum for Saramaccan (Ham 1999), also has a tritonal system. This is still short of four or five level tones typically found in Asian languages.

Saramaccan also has tone patterns associated with lexical categories, including patterns that distinguish verbs from other categories (Voorhoeve 1959, Byrne 1987:261):

(6) maaká 'to notice' versus $\mathrm{L}-\mathrm{L}-\mathrm{H}$ maák $\underline{a}$ 'portent' $\mathrm{L}-\mathrm{H}-\mathrm{L}$

In these cases, each mora (vowel) bears a different tone since the mora is the TBU.

On the other hand, postlexically, Saramaccan has tone spreading and no polarization. Tone spreading in Saramaccan results from postlexical rules (Ham 
1999). For example, a High $(\mathrm{H})$ tone in a word can spread over to following words (E - lax mid front vowel):

$\begin{array}{ll}\text { (7) dí hánso } & \text { mujéE } \\ \text { the beautiful } & \rightarrow \text { woman }\end{array} \quad$ dí hánsó mújéEE

In Saramaccan, the $\mathrm{H}$ tone of the determiner di spreads to the first syllable of the word $m u \dot{j} \dot{E} E$. It has unbounded spreading, including any number of syllables between two $\mathrm{H}$ tones with no intervening phrasal edges. Other postlexical phenomena includes downstepping.

Rountree (1972:312) has described cases of downstep in Saramaccan triggered by a following $\mathrm{L}$ tone:

(8) álá njan'j!án $d E$

there food is- $\mathrm{V}$

The $\mathrm{H}$ tone in ján lowers because the following verb carries $\mathrm{L}$ tone.

There are five important parameters in the typological classification of these Creole systems: the number of tone levels, the TBU, the assignment of patterns to lexical categories, tone spreading, and downstepping. These establish fundamental distinctions between West African and Asian tonal languages. TBUs, the assignment of patterns to lexical categories, and tone spreading also distinguish restricted from non-restricted tone languages that identify stages in the shift from tone to stress systems, being the non-restricted type the one closer to a pure tonal system. Indeed, Papiamentu exhibits more features of restricted systems than Saramaccan. The following section describes the main differences between Papiamentu and Saramaccan in more detail.

\section{Systems with one Lexically Prespecified Tone:}

Non-restricted tone languages must have constituted Papiamentu's substrata; and Saramaccan's substrata must have been stable non-restricted tone languages. Indeed, most slaves in Curaçao and those from which the Saramacca descended were Ewe (Kwa) speakers, currently a stable non-restricted tone language (Singler 1996, Ham 1999). Papiamentu exhibits some features of restricted tone languages, while Saramaccan is essentially a non-restricted tone language. However, as tone languages, both share more parametric similarities than differences.

Saramaccan and Papiamentu share the following features:

(A) Tone is distinctive at the lexical level. There are two level tones: $\mathrm{H}$ and $\mathrm{L}$.

(B) The mora is the TBU. Contour tones occur only in bimoraic sequences.

(C) Tonal patterns distinguish lexical categories.

(D) Phonological Words must have, at least, a syllable with $\mathrm{H}$ tone. However, these can have more than one $\mathrm{H}$ per word, resulting either from postlexical rules or lexical prespecification. 
(C) Spreading and Polarization are strictly local (no gaps).

- Spreading to morae unspecified for tone immediately following $\mathrm{H}$ tone.

- Polarization: Morae unspecified for tone receives a polarizing tone with respect to following tone.

(D) There are floating tones, tone conservation, and downstepping/downdrift.

What makes Papiamentu closer to a restricted tone language and different from Saramaccan includes the following:

(A) A different set of lexical categories carry tone patterns in each language, being Saramaccan a language with freer tone assignment and a smaller number of categories subject to tone patterns.

(B) Polarization, a feature of tone-to-stress systems, applies in Papiamentu, not Saramaccan.

(C) Accent has an important role in Papiamentu, with stress at the lexical level while Saramaccan has only phrase level stress assignment.

(D) Saramaccan has lexically assigned falling and rising contour tones, while Papiamentu has falling contour tones but rising contour tones resulting from postlexical rules only. Papiamentu has a smaller set of lexically assigned contour and level tones.

Both are tone languages even if Papiamentu exhibits more changes. Tone spreading, free tone assignment, and other typically tonal phenomena indicate the operation of a tonal, not a stress system (Hyman 1978). Differences found in Papiamentu indicate a shift towards an accentual system: (a) stress and tonal systems in which stress and $\mathrm{H}$ tone are attracted to accented monosyllables; (b) polarization; and (c) fixed tonal patterns with a single $\mathrm{H}$ tone dominate as lexical properties.

\section{Conclusions}

Typologically, Saramaccan and Papiamentu are not only tonal languages, but tonal languages related to each other by their typological affiliation to West African languages. This proposition is strong evidence for a genetic affiliation between these languages which lexifiers belong to different branches of the IndoEuropean family. Both are descendants of the same parents, probably a Kwa language like Ewe, or closely related languages in West Africa. 


\section{Typology and Tonogenesis in Two Atlantic Creoles}

\section{References}

Bao, Zhiming. 1992. Towards a Typology of Tone Sandhi. In L. A. BuszardWelcher, J. Evans, D. Peterson, L. Wee, and W. Weigel (eds.) Proceedings of the 18th Annual Meeting of the Berkeley Linguistics Society - Special Session on the Typology of Tone Languages. Berkeley: University of California Press.

Bendix, Edward H. 1983. Sandhi Phenomena in Papiamentu, other Creoles, and African Languages. In Lawrence D. Carrington (ed.) Studies in Caribbean Language. St. Augustine, Trinidad: Society for Caribbean Linguistics.

Byrne, Francis. 1987. Grammatical Relations in a Radical Creole: Verb Complementation in Saramaccan. Amsterdam/Philadelphia: John Benjamins Publishing Company.

Cassimjee, Farida \& Charles W. Kisseberth. 1992. Tonology of Depressor Consonants: Evidence from Mijikena and Nguni. In L. A. Buszard-Welcher, J. Evans, D. Peterson, L. Wee, and W. Weigel (eds.) Proceedings of teh 18th Annual Meeting of the Berkeley Linguistics Society - Special Session on the Typology of Tone Languages. Berkeley: University of California Press.

Chen, Matthew Y. 1992. Tone Rule Typology. In L. A. Buszard-Welcher, J. Evans, D. Peterson, L. Wee, and W. Weigel (eds.) Proceedings of teh 18th Annual Meeting of the Berkeley Linguistics Society - Special Session on the Typology of Tone Languages. Berkeley: University of California Press.

Greenberg, J. 1974. Language Typology: A historical and analytic overview. The Hague/Paris: Mouton.

Ham, William. 1999. Tone Sandhi in Saramaccan: A case of substrate transfer? Journal of Pidgin and Creole Languages 14: 45-91.

Harris, C. C. 1951. Papiamentu Phonology. Unpublished doctoral dissertation, Cornell University, New York.

Hyman, L. M. 1978. Tone and/or accent. In D.J. Napoli (ed.), Elements of tone, stress, and intonation. Washington, D.C.: Georgetown University Press.

Hyman, L. M. 1992. Tone in phonology. In W. Bright (ed.) International Encyclopedia of Linguistics Vol. 4. New York: Oxford University Press.

Hyman, Larry M. \& Francis X. Katamba. 1993. A New Approach to Tone in Luganda. Language 69.1: 34-67.

Kouwenberg, Silvia \& Eric Murray. 1994. Papiamentu. Languages of the World/materials 83. München/Newcastle: Lincom Europa.

McCawley, James D. 1978. What is a Tone Language? In Victoria A. Fromkin (ed.) Tone: A Linguistic Survey. New York: Academic Press.

Newman, Paul. 1995. Hausa Tonology: Complexities in an "Easy" Tone Language. In J. A. Goldsmith (ed.) The Handbook of Phonological Theory. Cambridge, Massachusetts: Blackwell.

Odden, D. 1989. Predictable Tone Systems in Bantu. In H. van der Hulst and N. Smith (eds.) Autosegmental Studies on Pitch Accent Systems. Dordrecht: Foris.

Odden, D. 1995. Tone: African languages. In J. A. Goldsmith (ed.) The Handbook of Phonological Theory. Cambridge, Massachusetts: Blackwell. 
Phillipson, Gérard. 1998. Tone Reduction vs. Metrical Attraction in the Evolution of Eastern Bantu Tone Systems. In L. M. Hyman and C. W. Kisseberth (eds.) Theoretical Aspects of Bantu Tone. Stanford, CA: CSLI Publications.

Pickering, Lucy \& Yolanda Rivera. 2001. Phonetic Correlates of Stress and Tone in a Mixed System. Ms. University of Puerto Rico-Río Piedras/University of Alabama-Tuscaloosa.

Pulleyblank, D. 1986. Tone in lexical phonology. Dordrecht, Holland: D. Reidel Publishing Company.

Rivera, Y. 1998. Tone and Stress in Papiamentu: the Contribution of a ConstraintBased Analysis to the Problem of Creole Genesis. Journal of Pidgin and Creole Languages 13.2: 1-38.

Römer, R. G. 1983. Papiamentu tones. In E. Muller (ed.) Papiamentu: Problems and possibilities, papers presented at the Conference on Papiamentu on the occasion of the 65th anniversary of Madero and Curiels Bank. Zutphen: De Walburg Pers.

Römer, R.G. 1991. Studies in Papiamentu Phonology (Caribbean Culture Studies). Amsterdam and Kingston: The University of Amsterdam.

Rountree, Catherine S. 1972. Saramaccan Tone in Relation to Intonation and Grammar. Lingua 29: 308-325.

Salmons, Joe. 1992. Diachronic Typology and Tone-to-Stress Shift. The Journal of IndoEuropean Studies 20.3-4: 269-281.

Schuh, Russell G. 1978. Tone Rules. In Victoria A. Fromkin (ed.) Tone: $A$ Linguistic Survey. New York: Academic Press.

Singler, John V. 1996. Theories of Creole Genesis, Sociohistorical Considerations, and the Evaluation of Evidence: The Case of Haitian Creole and the Relexification Hypothesis. Journal of Pidgin and Creole Languages 11.2: $185-230$.

Voorhoeve, Jan. 1959. An Orthography for Saramaccan. Word 15: 436-445.

Voorhoeve, Jan. 1961. Le ton et la grammaire dans le Saramaccan. Word 17: 146163.

Voorhoeve, Jan. 1968. Towards a Typology of Tone Systems. Linguistics 46: 99114.

Yip, Moira. 1995. Tone in East Asian Languages. In J.A. Goldsmith (ed.) The Handbook of Phonological Theory. Cambridge, Massachusetts: Blackwell.

\author{
P.O. Box 22742
}

San Juan, P.R. 00931

riveray@coqui.net

rivera@bama.ua.edu 